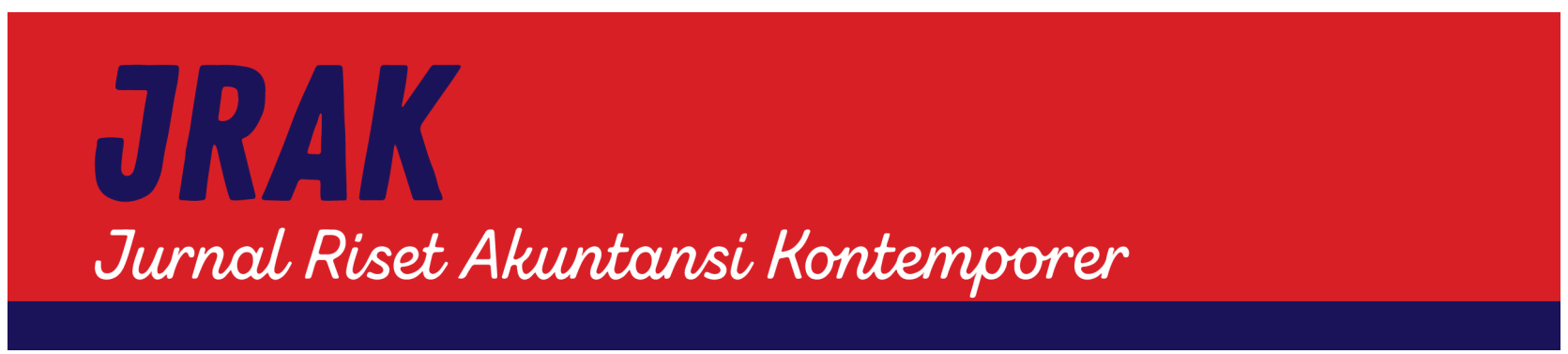

\title{
FRAUD PENTAGON THEORY FOR DETECTING FINANCIAL STATEMENT FRAUDULENT
}

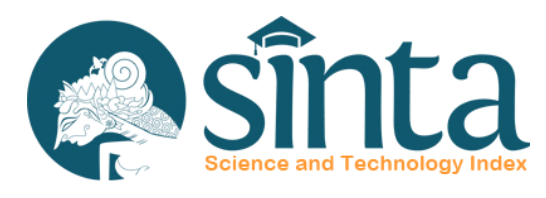

https://journal.unpas.ac.id/index.php/jrak/index

\author{
Rif'atul Fitriyah ${ }^{1} \bowtie$, Santi Novita ${ }^{2}$ \\ ${ }^{1,2}$ Universitas Airlangga \\ $\triangle$ rifatul.fitriyah-2019@feb.unair.ac.id \\ Jl. Airlangga, Airlangga, Kec. Gubeng, Kota Surabaya
}

\section{Article Info}

History of Article

Received: $1 / 1 / 2021$

Revised: $7 / 3 / 2021$

Published: $25 / 4 / 2021$

Jurnal Riset Akuntansi Kontemporer

Volume 13, No. 1, April 2021, Page 20-25

ISSN 2088-5091 (Print)

ISSN 2597-6826 (Online)

Keywords: arrogance; capability; financial statement fraudulent; opportunity; pressure; rationalization; state-owned enterprises

\begin{abstract}
Cases of fraud from 2019 to 2020 in Indonesia involve companies of state-owned enterprises. This study aimed to analyze the factors that encourage financial statement fraudulent with analysis of fraud pentagon theory. This research analyzes the influence of variable pressure proxied by financial stability, opportunity proxied by auditor change, rationalization proxied by audit opinion, capability proxied by change of directors and arrogance proxied by the number of CEO's. This reserach uses 100 of State-Owned Enterprises companies listed on Indonesia Stock Exchange in the period 2015-2019. Data analyzed by using logistic regression. The results showed that pressure and opportunity influence the financial statement fraudulent, while rationalization, capability, and arrogance have not.
\end{abstract}

\section{INTRODUCTION}

Nowadays, the companies all over the world face various challenges, such as globalization, fast-growing technology, rapid development in industry and business, risk, as well as complexity of information and data management (Siregar and Tenoyo, 2015). These changes have made the risk of fraud faced by the company increased substantially (Han, 2017). In response to this, entities are now more aware of the need to have methods of detection and prevention of financial statement fraudulent that are proactive in minimizing the potential risk of fraud (Wu and Huang, 2013).

Fraud cases that have gained attention since the end of 2019 to early 2020 are cases involving state-owned companies, which are PT. Garuda Indonesia and Asuransi Jiwasraya (AJS). On January 8, 2020, BPK-RI confirmed that the auditor AP's opinion on AJS' 2017 financial report was an "adverse opinion" because AJS had Rp. 7 trillion technical reserve deficit. This shows that the profit announced by AJS in 2017, which is Rp. 360 billion, is not correct. Instead, AJS suffered Rp. 7 trillion loss.

Year 2019 is also not a lucky year for PT. Garuda Indonesia (Siddiq and Suseno, 2019). Garuda Indonesia's financial statement was considered odd after their partnership with Mahaka was recorded as income. This fund was supposed to be regarded as receivables, but Garuda Indonesia treated it as income. As a result, Garuda, which previously had a loss, was able to report a profit. 
Fraud refers to deliberate deception which includes financial statement fraudulent as well as theft, embezzlement or employee deflation (Gullkvist and Jokipii, 2013). One form of financial statement fraudulents is the misappropriation of assets. This is also an important thing because it is substantive in nature and can have an impact on company value and credibility (Song, et al., 2013). Financial statement fraudulent is an issue that cannot be underestimated (Sawaka and Ramantha, 2020). The auditor must be able to consider the possibility of fraud from various perspectives (Nigrini, 2019). One theory that is often used to assess fraud is the fraud triangle theory coined by Cressy in 1953.

Over time, the fraud triangle theory has developed. This development was put forward by Wolfe and Hermanson in 2004, proposing the development of the fraud triangle theory into fraud diamond theory by adding one element that is believed to have a significant effect on fraud, namely capability (Danuta, 2017). The development didn't stop there, as Crowe also refined the theory coined by Cressy. Crowe found that one more element, arrogance, also contributed to the occurrence of fraud. Research conducted by Crowe included the fraud triangle theory, as well as element capability proposed by Wolfe and Hermanson in it, so that the fraud model proposed by Crowe consists of five indicators, which are pressure, opportunity, justification, capability and arrogance. This theory was presented in 2011 and named as Crowe's fraud pentagon theory.

The first element of fraud pentagon theory is pressure. Perceived pressure is related to the motivation that leads to financial statement fraudulent behavior. Every perpetrator of financial statement fraudulent faces some type of pressure to commit the fraud (Feldman and Halali, 2019). Words become very important things related to pressure, because pressure is not always a concrete action. When the perpetrators believe that they are being pressured, that belief can lead to financial statement fraudulent.

Rationalization refers to an act which states that financial statement fraudulent isn't a crime. If the perpetrator cannot justify the financial statement fraudulent, it is unlikely that the perpetrator will commit the fraud (Shi, et al., 2017). Capability is a characteristic or skill that is needed by someone in committing financial statement fraudulent (Abdullahi and Mansor, 2015). The perpetrator recognize the opportunity, and then using their capability to turn it into a reality. Position, intelligence, ego, coercion, cheating and stress are supporting elements of capability. Not everyone has the motivation, opportunity and realization to commit financial statement fraudulent, due to the lack of capability to do or hide them. Capability is a very important element when it comes to the long-term financial statement fraudulent.

Research conducted by the Committee of Sponsoring Organizations of the Treadway Commission (COSO) found that $70 \%$ of frauds occur as a result of pressure and greed, and that $89 \%$ of fraud cases involve the CEO (Yulianti, et al., 2019). The number of CEO's picture listed in the annual report can represent the level of arrogance and excellence possessed by the CEO. The level of arrogance is a condition where a management over their arrogance does not comply with the internal controls that exist in a company due to status and position reasons (Nindito, 2018).

Researches conducted by (Umar, et al., 2020; Handoko and Natasya, 2019; Irwandi, et al., 2019) shows that pressure has an effect on financial statement fraudulent, while researches conducted by (Wahyuningrum and Iswajuni, 2020; Yulianti, et al., 2019) shows the opposite. Research conducted by (Utomo, et al., 2019) shows that opportunity affects financial statement fraudulent, but on the contrary, researches conducted by (Yulianti, et al., 2019; Indarto and Ghozali, 2016) give evidence that opportunity doesn't affect financial statement fraudulent. Research carried out by (Umar, et al., 2020) shows that rationalization has an effect on financial statement fraudulent, meanwhile research from (Irwandi, et al., 2019) shows that rationalization doesn't have an effect on financial statement fraudulent. Research conducted by (Umar, et al., 2020) gives evidence that capability affects financial statement fraudulent, whereas researches conducted by (Handoko and Natasya, 2019; Yulianti, et al., 2019) gives contradictive result. Research from (Yulianti, et al., 2019) shows that arrogance doesn't have an effect on financial statement fraudulent.

The purpose of this study is to analyze the factors that have an effect on the occurrence of financial statement fraudulent based on the perspective of fraud pentagon theory in the state-owned companies listed on the IDX for 2015-2019 period.

\section{METHOD}

This research is a quantitative study that examines the effect of the fraud pentagon theory on financial statement fraudulent. The measurement of the variables in this study will be presented in Table 1 .

The population in this study is all of state-owned companies listed on the IDX for the 2015-2019 period. This study uses a saturated sample as sampling technique, in which all members of the population are included as the sample in this study, because the number of listed state-owned companies in Indonesia is only 20 companies. The data analysis technique used in this study is logistic regression analysis. 
Table 1. Operationalization of Variables

\begin{tabular}{ll}
\hline \multicolumn{1}{c}{ Variable } & \multicolumn{1}{c}{ Measurement } \\
\hline Pressure & \multicolumn{1}{c}{ Fraud Pentagon Theory $(\mathrm{X})$} \\
& ACHANGE $=\frac{\text { Total Asset }_{\mathrm{t}}-\text { Total Asset }_{\mathrm{t}-1}}{\text { Total Asset }_{\mathrm{t}}}$ \\
Opportunity & 0: No change of auditor; 1 : conducting change of auditor \\
Rationalization & $0:$ Unqualified audit opinions; 1. Audit opinions outside unqualified opinion \\
Capability & $0:$ No change of directors; 1. Conducting change of directors \\
Arrogance & The number of CEO's pictures displayed on company annual report \\
\hline & \multicolumn{1}{c}{ Constant } \\
\hline Beneish M-Score & $-4,84+0,92 *$ DSRI $+0,528 *$ GMI $+0,404 *$ AQI $+0,892 *$ SGI $+0,115 *$ \\
& DEPI $-0,172 *$ SGAI $+4,679 *$ TATA $-0,327 *$ LVGI \\
\hline
\end{tabular}

Source: data processed by researcher, 2020

\section{RESULT}

Table 2 shows the regression equation in this study, as follows:

$$
\text { In } \frac{\text { prob }_{\mathrm{KLK}}}{1-\text { prob }_{\mathrm{KLK}}}=-1.141+3.718 \mathrm{X}_{1}+0.988 \mathrm{X}_{2}-0.514 \mathrm{X}_{3}-0.200 \mathrm{X}_{4}+0.009 \mathrm{X}_{5}+\varepsilon
$$

\section{Description:}

$$
\begin{array}{ll}
\text { In } \frac{\text { prob }_{\mathrm{KLK}}}{1-\text { prob }_{\mathrm{KLK}}} & =\text { Financial statement fraudulent } \\
\mathrm{X}_{1} & =\text { Pressure } \\
\mathrm{X}_{2} & =\text { Opportunity } \\
\mathrm{X}_{3} & =\text { Rationalization } \\
\mathrm{X}_{4} & =\text { Capability } \\
\mathrm{X}_{5} & =\text { Arrogance }
\end{array}
$$

Table 2. Logistic Regression Analysis

\begin{tabular}{lcccccc}
\hline & B & S.E. & Wald & df & Sig. & Exp (B) \\
\hline Pressure & 3.718 & 1.552 & 5.735 & 1 & 0.017 & 41.162 \\
Opportunity & 0.988 & 0.456 & 4.702 & 1 & 0.030 & 2.686 \\
Rationalization & -0.514 & 0.455 & 1.279 & 1 & 0.258 & 0.598 \\
Capability & -0.200 & 0.465 & 0.185 & 1 & 0.667 & 0.819 \\
Arrogance & 0.009 & 0.103 & 0.008 & 1 & 0.930 & 1.009 \\
Constant & -1.141 & 0.607 & 3.538 & 1 & 0.060 & 0.319 \\
\hline
\end{tabular}

Source: data processed by researcher, 2020

Table 3 shows the results of the feasibility test on regression models Cox and Snell $\mathrm{R}^{2}$ and Nagelkerke $\mathrm{R}^{2}$. The result shows the coefficient of determination with Nagelkerke $\mathrm{R}^{2}$ value of 0.184 . This means that the independent variables are able to explain the dependent variable by $18.4 \%$ and the remaining $81.6 \%$ is explained by other variables which are not used in this study.

Table 3. Feasibility Test of Regression

Model Coc and Snell $\mathrm{R}^{2}$ and Nagelkerke $\mathrm{R}^{2}$

\begin{tabular}{cc}
\hline Cox and Snell $\mathrm{R}^{2}$ & Nagelkerke $\mathrm{R}^{2}$ \\
\hline 0,137 & 0,184 \\
\hline
\end{tabular}

Source: data processed by researcher, 2020 
Table 2 also shows the results of hypothesis testing for each variables and opportunity have significance level smaller than $\alpha(0,05)$, that means affects financial statement fraudulent. Rationalization, capability, and arrogance have significance level greater than $\alpha$, that mean have no effect on financial statement fraudulent.

\section{DISCUSSION}

Table 4 shows the results of the descriptive statistics analysis of the variables in this study.

Table 4. Descriptive Statistic Analysis

\begin{tabular}{lccccc}
\hline & $\mathrm{N}$ & Min & Max & Mean & Std. Deviation \\
\hline Financial Statement Fraudulent & 100 & 0 & 1 & 0,42 & 0.496 \\
Pressure & 100 & -9.61 & 0.90 & 0.0496 & 0.99249 \\
Opportunity & 100 & 0 & 1 & 0,58 & 0,496 \\
Rationalization & 100 & 0 & 1 & 0,57 & 0,498 \\
Capability & 100 & 0 & 1 & 0,35 & 0,479 \\
Arrogance & 100 & 1 & 14 & 4,06 & 2,155 \\
Valid N (listwise) & 100 & & & & \\
\hline Source: data processed by researcher, 2020 & & & &
\end{tabular}

Source: data processed by researcher, 2020

Financial statement fraudulent, pressure, and capability have mean value which are smaller than the standard deviation value, it can be concluded that the data is heterogeneous or tends not to be in groups. Opportunity, rationalization, and arrogance have mean value which are greater than the standard deviation value.

The test result for the first hypothesis indicates that pressure has an effect on financial statement fraudulent. This result is in line with the results of researches conducted by (Umar, et al., 2020; Handoko and Natasya, 2019; Irwandi, et al., 2019), but it is contradictive with the results of researches conducted by (Wahyuningrum and Iswajuni, 2020; Yulianti, et al., 2019). The unstable company financial stability can encourage the company management to commit financial statement fraudulent. Total assets are considered as a representation of the wealth owned by the company. If a company has high total assets, so the company is also considered to have high wealth. It is expected to be able to attract investors to invest because the returns that will be received will be maximized. Likewise, if the company's total assets decline, the company management will be considered unable to manage the company's assets and there will be obstacles to the flow of funds and investment in the company. Such conditions will put pressure on management to commit financial statement fraudulent, to make sure the high total assets in the company, so the management will be considered as capable of managing funds and investments properly and wisely.

The test result for the second hypothesis shows that opportunity has an effect on financial statement fraudulent. This result is in line with the result of the research conducted by (Utomo, et al., 2019), whilst is contradictive with the result of the researches conducted by (Yulianti, et al., 2019; Indarto and Ghozali, 2016). The purpose of a company to change the auditors is to reduce the risk of the detection of financial statement fraudulent by the old auditors. In addition, the change of auditors is also considered as an attempt to eliminate the evidences or audit trails that were found by the previous auditors. Companies that change auditors can be indicated that there is financial statement fraudulent in the company. The old auditor may have found the traces of the company fraud, and when the company management discovers this, the company management will decide to change the auditors to eliminate the audit trail in future periods. In the end, it is also expected that the change of the auditors carried out by the company will make the old auditors unaware of more financial statement fraudulent that have occurred in the audited company.

The test result for the third hypothesis shows that rationalization has no effect on financial statement fraudulent. This result is in line with the research conducted by (Irwandi, et al., 2019), while this result is opposite of the result from the research conducted by (Umar, et al., 2020). An audit opinion can describe the company's financial condition, including an indication of whether or not there is financial statements fraudulent in the company. Audit opinion is a form of statement given by the auditor on the fairness of a company's financial statements. The level of materiality determined by the auditor is sometimes tolerated by the auditor, so that the auditor is still be able to provide an unqualified opinion. However, the tolerance given by the auditor was in the end considered by the company management as something that was not an error, so that in the next period, it will still be done and the auditors still consider this as something that doesn't indicate financial statement fraudulent. Furthermore, most of the unqualified audit opinions provided by the auditors are not completely 
pure unqualified opinions. Some of the unqualified audit opinions are still accompanied by an emphasis on one thing or additional explanation, usually called as modified unqualified opinion. This clearly indicates that the audit opinion is not absolutely free from material misstatement or financial statement fraudulent.

The test result for the fourth hypothesis shows that capability doesn't affect financial statement fraudulent. This result is consistent with the results of the researches conducted by (Handoko and Natasya, 2019; Yulianti, et al., 2019), yet it contradicts the research's result from (Umar, et al., 2020). This is because the main objective of the change of the directors of a company is to replace less competent directors with more competent ones in order to improve the company's performance. Eventually, when the company's performance has increased, it can attract investors to invest in the company. Moreover, each company also has its own policy for conducting director rotation, for example there are companies that enforce a director rotation policy for every 5 years, 3 years or even once a year. This is something that generally occurs in every company, depending on the policies of each company. Generally, when there is a rotation of the board of directors, the policies determined by the previous board of directors might be adjusted or changed. This change of policy is expected be able to minimize the occurrence of company's financial statement fraudulent.

The test result for the fifth hypothesis gives indication that arrogance doesn't have any effects on financial statement fraudulent. This result is consistent with the result of the research conducted by (Yulianti, et al., 2019). The number of CEO's pictures displayed in the company's annual report cannot be taken as a form of CEO's greed. More pictures of the CEO displayed in the company's annual report can be a form of showing the achievements that the CEO has made during his tenure. More achievements made by the CEO represent the CEO's good and reliable performance. In addition, more CEO pictures displayed in the company's annual report can also indicate the CEO's high level of confidence. This high level of self-confidence also has a positive impact in leading a company. The confidence that the CEO has is likely obtained on the basis of the successes and achievements he has achieved, which may also be the various kinds of achievements obtained from his hard work so far to show his capability in advancing a company to the investors.

Generally, the result of this study indicate that out of the five independent variables used in this study, only two variables have an effect on financial statement fraudulent, while the other three variables have no effect on financial statement fraudulent. This could happen considering that the population and samples used in this study is State-Owned Enterprises that are still under the supervision and management of the Government. It might be not easy to commit financial statement fraudulent within state-owned organizations. Eventhough previously two state-owned companies (Garuda Indonesia and Jiwasraya Insurance) were proven to have committed financial statement fraudulent, this cannot be generalized to all of state-owned companies. The regulations relating to internal control mechanisms to detect and prevent financial statement fraudulent within state-owned companies are surely more stringent if compared to private companies, considering that stateowned companies are companies that are managed and supervised by the Government.

\section{CONCLUSIONS}

Rationalization proxied by the audit opinion, capability proxied by the change of directors and arrogance proxied by the number of CEO's picture have no effect on financial statement fraudulent, while pressure proxied by the financial stability and opportunities proxied by the change of auditors have an effect on financial statement fraudulent. This indicates that the fraud pentagon theory cannot be used in detecting financial statement fraudulent at state-owned companies listed on the IDX for the 2015-2019 period, regardless of the phenomena that occurred at PT. Garuda Indonesia and Asuransi Jiwasraya. The reason of this result is because BUMN surely have stricter regulations compared to private companies in monitoring and detecting financial statement fraudulent, so it is not easy for companies under the state scope to commit financial statement fraudulent.

\section{REFERENCES}

Abdullahi, R., Mansor, N. 2015. Fraud Triangle Theory and Fraud Diamond Theory. Understanding the Convergent and Divergent for Future Research. International Journal of Academic Research in Accounting, Finance and Management Sciences 5. doi: 10.6007/IJARAFMS/v5-i4/1823.

Danuta, K. 2017. Crowe's Fraud Pentagon Theory dalam Pencegahan Fraud pada Proses Pengadaan melalui E-Procurement. Jurnal Kajian Akuntansi 1. doi: 10.33603/jka.v1i2.826.

Feldman, Y., Halali, E. 2019. Regulating "Good" People in Subtle Conflicts of Interest Situations. Journal of Business Ethics 154, 1.

Gullkvist, B., Jokipii, A. 2013. Perceived Importance of Red Flags Across Fraud Types. Critical Perspectives on Accounting 24. 
Han, D. 2017. Researches of Detection of Fraudulent Financial Statements Based on Data Mining. Journal of Computational and Theoretical Nanoscience 14, 32-36.

Handoko, B.L., Natasya. 2019. Fraud Diamond Model for Fraudulent Financial Statement Detection. International Journal of Recent Technology and Engineering 8, 3. doi: 10.35940/ijrte.C5838.098319.

Indarto, S.L., Ghozali, I. 2016. Fraud Diamond: Detection Analysis on the Fraudulent Financial Reporting. Risk Governance and Control: Financial Markets and Institutions 6.

Irwandi, S.A., Faisal, Imam, G., Imang, D.P. 2019. Detection Fraudulent Financial Statement: Beneish M-Score Model. Wseas Transactions on Business and Economics 16.

Krishnan, G., Peytcheva, M. 2019. The Risk of Fraud in Family Firms: Assesments of External Auditors. Journal of Business Ethics 157.

Nigrini, M.J. 2019. The Patterns of the Numbers used in Occupational Fraud Schemes. Managerial Auditing Journal 34,5.

Nindito, M. 2018. Financial Statement Fraud: Perspective of the Pentagon Fraud Model in Indonesia. Academy of Acounting and Financial Studies Journal 22, 2.

Sawaka K., I.G.N.H., Ramantha, I.W. 2020. Fraud Pentagon Theory in Detecting Financial Perception of Financial Reporting with Good Corporate Governance as Moderator Variable. International Research Journal of Management, IT and Social Sciences 7. doi: 10.21744/irjmis.v7n1.824.

Shi, W., Connelly, B. L., Hoskisson, R. E. 2017. External Corporate Governance and Financial Fraud: Cognitive Evaluation Theory Insights on Agency Theory Prescripstions. Strategic Management Journal 38.

Siddiq, F., Suseno, A. 2019. Fraud Pentagon Theory dalam Financial Statement Fraud Pada Perusahaan Terdaftar di Jakarta Islamic Index (JII) Periode 2014-2017 (Perspektif F-Score Model). Jurnal Nusantara Aplikasi Manajemen Bisnis 4. doi: 10.29407/nusamba.v4i2.13800.

Siregar, S. V., Tenoyo, B. 2015. Fraud Awareness Survey of Private Sector in Indonesia. Journal of Financial Crime 22, 3.

Song, D.B., Lee, H.Y., Cho, E.J. 2013. The Association between Earnings Management and Asset Misappropriation. Managerial Auditing Journal 28, 6.

Umar, H., Partahi, D., Purba, R. 2020. Fraud Diamond Analysis In Detecting Fraudulent Financial Report. International Journal of Scientific \& Technology Research 9.

Utomo, S. D., Machmuddah, Z., Pamungkas, I.D. 2019. The Effect of Auditor Switching and Managerial Ownership on Fraudulent Financial Statement. Wseas Transactions on Business and Economics, 16.

Wahyuningrum, L., Iswajuni. 2020. The Factors Affecting Fraudulent Financial Reporting in the Fraud Triangle Perspective. International Journal of Innovation, Creativity and Change 11, 9.

Wu, W. Y., Huang, C.H. 2013. Motives and Likelihood of Bribery: An Experimental Study of Managers in Taiwan. Ethics \& Behavior 23, 4.

Yulianti, S. R. P., Yuni, S.W., Lulus, P. 2019. Influence of Fraud Pentagon Toward Fraudulent Financial Reporting in Indonesia an Empirical Study on Financial Sector Listed in Indonesian Stock Exchange. International Journal of Scientific and Technology Research 8, 8. 